\title{
Short Stature Homeobox Protein
}

National Cancer Institute

\section{Source}

National Cancer Institute. Short Stature Homeobox Protein. NCI Thesaurus. Code C75405.

Short stature homeobox protein (292 aa, $\sim 32 \mathrm{kDa}$ ) is a proliferation protein that is encoded by the human SHOX gene and is involved in transcription and growth. 